\title{
901 乾燥・砂漠地帯に埋設された地雷の赤外線探査
}

\section{Application of Infrared Remote Sensing for Mine Exploration in Desert Zones}

\author{
正 稲垣照美（茨城大） \\ 稲熊和之（東京電力）
}

\author{
○北山真司（茨城大院） \\ 内田亮祐（茨城大）
}

\author{
Terumi INAGAKI ${ }^{1}$, Masashi KITAYAMA ${ }^{1}$, Kazuyuki INAGUMA ${ }^{2}$, Ryousuke UCHIDA ${ }^{1}$ \\ ${ }^{1}$ Ibaraki University, Nakanarusawa 4-12-1, Hitachi, Ibaraki, 316-8511, Japan \\ ${ }^{2}$ Tokyo Electric Power Company, Uchisaiwai 1-1-3, Chiyoda, Tokyo, 100-8560, Japan
}

\begin{abstract}
Infrared thermography detects thermal energy emitted from various objective surfaces, and it is a procedure for evaluating the surface temperatures nondestructively. We can diagnose and evaluate a two-dimensional temperature field having complicated shape every real-time pixel by using this technique, if an appropriate image processing technique is combined. The technique has therefore widely been used for various applications such as engineering, medical and industrial utilizations. In this paper the applicability of infrared sensing to nondestructive diagnosis for invisible mines installed in desert zones is experimentally and numerically investigated with the aid of an appropriate mathematical modeling.
\end{abstract}

Key Words: Infrared Sensing, Nondestructive Testing, Numerical Analysis, Mine Exploration

\section{1. 緒言}

赤外線サーモグラフィーは，対象物から発せられる熱エネ ルギーを検知し；その表面温度場をリモートセンシングに評 価する手段である. 本研究では, このような赤外線センシン

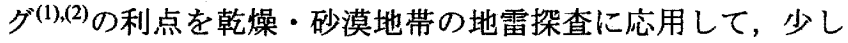
でも作業に関わる危険を低減する技術の可能性について，実 計測及び数値シミュレーションの観点から探査に付随するメ カニズム，探査限界及び探査に付随する影響・因子などにつ いて検討を加えた.

\section{2. 実験及び数值計算法}

実験では, 幅 $300[\mathrm{~mm}]$, 長さ $300[\mathrm{~mm}]$, 深さ $400[\mathrm{~mm}]$ の 内壁に断熱材を貼り巡らせた矩形状の木箱を用意し, 内部に 砂を充填して乾燥・砂漠地帯の地中を再現し, 中央部の地中 に模型地雷を埋設した.この模型は, プラスチック地雷を想 定して外部をべークライト樹脂, 内部に火薬の代わりに砂を 充填し，上面にはゴムを付加した。実験は，午前 6 時に測定 を開始し, 翌日午前 6 時に測定を終了する計 24 時間とした. 実験時では, 太陽熱流束, 風速, 気温, 湿度などに加え, 地 雷上部の地表面温度についても計測している。また，地雷上 部の地表面温度場を赤外線サーモグラフィーで 3 時間毎に計 9 回計測した.

数值シミュレーションでは, 内部に地雷を有する三次元物 理モデルを構築した。 ここで, 地表面を加熱面かつ放熱面と し，その他の 5 面（側面及び底面）を断熱面とした. 三次元 数值シミュレーションには, 基礎方程式として非定常三次元 熱伝導方程式を用いた。これらに使用した初期条件及び境界 条件の詳細は,前報(3)を参照されたい。

また, 計算では, 三次元非定常熱伝導方程式をPatankarの コントロールボリューム法(4)に基づき差分化し, ADI法で各 時間の非定常解を得た。計算は, 地雷の存在する状況下で 24 時間計算した後の諸量を基に次の 24 時間, すなわち午前 6 時から翌朝午前 6 時までの計算を行っている.

\section{3. 結果及び考察}

Fig.1は, 周辺土壌を砂とし, 地表面から地雷までの距離が $10[\mathrm{~mm}]$ の実験で得た熱画像である。日中は,地雷上部が周辺 部より温度が高く，夜間は温度が低いことがわかる．Fig.2 は $10[\mathrm{~mm}], 30[\mathrm{~mm}], 50[\mathrm{~mm}], 70[\mathrm{~mm}]$ の場合の数值シミュレ ーション結果であり, 日の出後 $6[\mathrm{~h}]$ における地表面の 2 次元
熱画像である．画像中，赤色が相対的に高温領域，青色が相 対的な低温領域を示している。地雷深度が大きくなるにつれ て,地雷イメージが不鮮明になっているのがわかる.

Fig.3は, Fig.2に示した数值シミュレーション結果を基に 算出した地表面の温度差(地雷上部とその周辺の地表面温度) を表したものである. 地表面から地雷までの距離が大きくな るにつれて温度差が小さくなっていることがわかる.すなわ ち, 埋設深度が大きくなるにつれて, 地雷が不鮮明になり, 赤外線サ一モグラフィーによる地雷探查が難しくなる.

Fig.4 は,地表面から地雷までの距離を $10[\mathrm{~mm}]$ とし, 想定 される様々な土壌環境(砂, 砂利, 粘土, 有機質土)に対して数 值シミュレーションした結果を基に算出した地表面の温度差 である，なお，砂利，粘土，有機質土の地表面放射率は,文献 データを参照して，それぞれ $0.88,0.85,0.95$ としてある. 地 雷周辺土袞が砂, 砂利, 粘土, 有機質士の場合を比較すると, 砂利, 粘土, 砂, 有機質土の順に温度差が大きくなっている. これは, 地雷の熱特性と周辺土㙵の熱特性の差が相対的に大 きいほど温度差が生じることに起因する。これから, 地雷周 辺の土質によっても探查能が左右されることがわかる.

Fig.5は, 砂中に地雷を $10[\mathrm{~mm}]$ 埋設して同じ気象条件の下, 地雷サイズを変化させた場合の数值シミュレーションによる 2 次元熱画像である. (a), (b), (c)は，通常の地雷寸法の高 さ(DZ)は変えず, 幅(DX, DY)のみを変化させた. 幅が大き いほど地雷イメージが鮮明になっていく.(d), (e)，(f)は，全 ての地雷寸法を変化させてある. 地雷が大きいほど地雷イメ ージが鮮明になっている. また, Fig.6からも, 地雷寸法が大 きいほど地雷上部と周辺部との温度差は大きくなることがわ かる.これは, 地表面からの熱流が地雷部を避けて流れ, 地 雷上部の地表面近傍で熱流が滞る際に, 寸法の大きい方がよ り熱流を滞らせる結果生じるためと考えられる。このことか ら，地雷寸法によっても探查能が左右されることがわかる.

Fig.7 は, 周辺土壤の砂の含水率を $0[\%], 5[\%], 10[\%], 15[\%]$, $20[\%], 30[\%]$ と変化した場合の数值シミュレーションした結 果を基にした地表面の温度差である. 含水率 $0[\%]$ の場合，砂 よりも地雷の構成材料であるべークライト樹脂の熱拡散率が 大きいため，日中では地表面からの熱流が地雷上部の地表面 を流れ,地雷上部の地表面以外では熱流が滞る結果生じるた めと考えられる．また，夜間でも地中からの熱流が地雷部を 
流れ，地雷上部の地表面以外では熱が蓄積されにくく，地雷 上部の地表面温度がその周辺部より高温となる. 含水率 $5[\%]$ 以上は，日中に温度差が正,夜間に温度差が負になる。また， 含水率 $10[\%]$ 未満では, 温度差が少ないため, 探査が困難と なる。この結果から，含水率が高ければ温度差が大きくなり やすく，探査能が向上する可能性があると考えられる.

Fig.8は，地表面の放射率を 1.0 から 0.8 まで 6 段階に分割 し,周辺土壌を砂, 埋設梁度を $10[\mathrm{~mm}]$ とした数值シミュレー ション結果であり，地表面の二次元熱画像である. 地表面放 射率の高い部分は，入射するエネルギーを相対的に受けやす いため地表面温度が早く上昇し, 地雷上部の地表面温度と差 が縮小するため, 地雷イメージが不鮮明になる可能性がある.

\section{4. 結言}

本研究は, 赤外線センシングの利点を地雷探査に态用して, 探査・除去作業に関わる危険について, 実計測及び数值シミ ユレーションの観点から探査に付随するメカニズムや探查限 界について検討を加えたものである. その結果, 以下のことが 明らかになった。

(1)太陽放射や自然環境条件を援用した赤外線センシングの 地雷探査では，地表面放射率や日射時間帯により探查に最 適な環境条件が存在する。

(2)地表面から地雷までの距離が大きくなるにつれて地雷上 部の地表面とその周辺部の温度差が小さくなり地雷イメー ジは不明瞭となる. 気象条件を利用した場合は, 計算上 $50[\mathrm{~mm}]$ 以上の埋設深度になると探查が困難になる。

(3)地雷の熱特性と周辺土壌の熱特性の差が相対的に大きい ほど温度差が生じ, 地雷イメージが明膫となる. 計算上は,

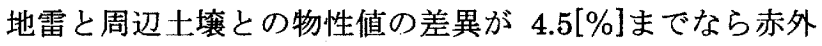
線探査が可能である.

(4)地雷寸法は, 寸法の大きい方が地表面からの熱流をより滞 りやすいため, 地雷上部と周辺部との温度差が大きくなり 地雷イメージが明膫となるため，探査能が向上する.

(5)含水率が $10[\%]$ 末満の場合, 地雷イメージが不鮮明になる が, 10[\%]以上であれば, 地雷イメージは鮮明になりやすく， 探査能が向上する.

(6)地表障害物等で放射率が種々に変化している地表面は, 探 查が難しくなる.これに対して,放射率の特定し易い砂漠地 帯では,赤外線地雷探査が比較的容易である. 計算上は,地表 面の放射率の $0.92 \sim 0.84$ までなら赤外線探査が可能である.

\section{参考文献}

(1) Inagaki, T. , and Y. Okamoto, Measurement of Turbulent Heat Transfer Coefficients Using Infrared Thermography near Ambient Conditions and Its Quantitative Error Estimation, J. of JSME International, Series B, Vol. 42, No. 2, (1999), 275.

(2) Inagaki, T. , et. al., Nondestructive Testing HANDBOOK 3rd. ed (Editor: Xavier P. V. Maldague and Patrick O. Moore)., ASNT, (2001).

(3) 稲垣照美, 他 2 名, 乾燥・砂漠地带の地雷探査に向けた 赤外線リモートセンシングの応用, (2006), 153.

(4) Suhas V. Patankar, Heat and Mass Transfer in Boundary Layers, 2nd ed., Intertext Books (1970)

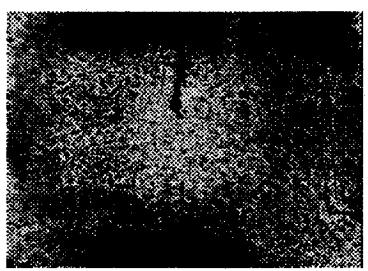

(a)6[h] after sunrise

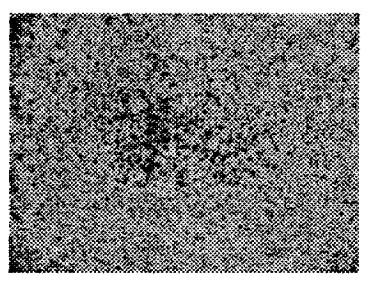

(b) $15[\mathrm{~h}]$ after sunrise
Fig.1 Transient Thermal Image Using Infrared Thermograhy

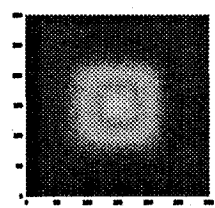

(a) $10[\mathrm{~mm}]$

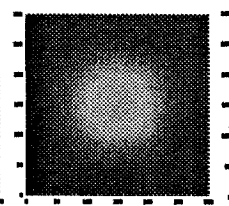

(b) $30[\mathrm{~mm}]$

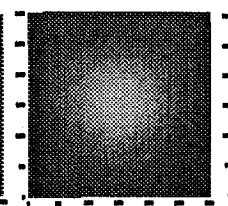

(c) $50[\mathrm{~mm}]$
Fig.2 Transient Thermal Images

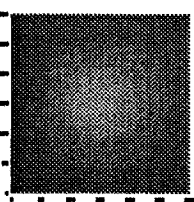

(d) $70[\mathrm{~mm}]$

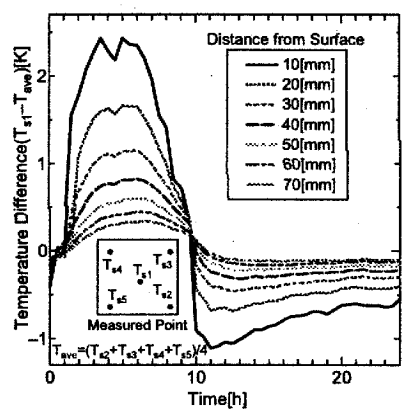

Fig.3 Influence of Buried Depth

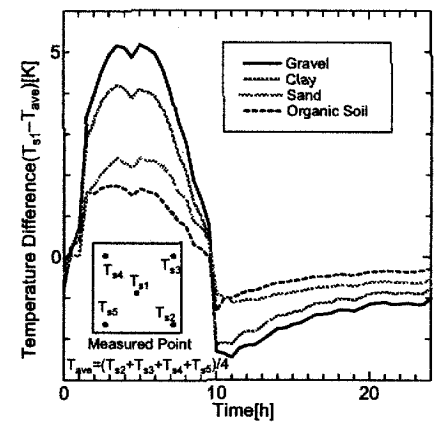

Fig.4 Influence of Soil Type

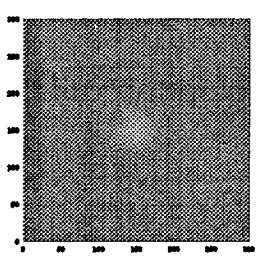

(a)Quarter Size $(\mathrm{DX} \times \mathrm{DY})$

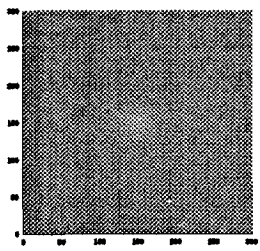

(d)Quarter Size

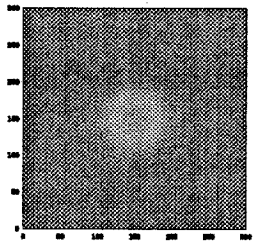

(b)Half Size

$(\mathrm{DX} \times \mathrm{DY})$

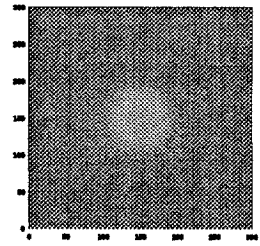

(e)Half Size

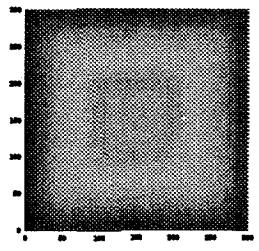

(c)Twice Size $(\mathrm{DX} \times \mathrm{DY})$

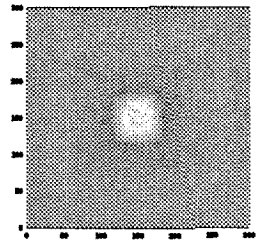

(f)Twice Size
$(\mathrm{DX} \times \mathrm{DY} \times \mathrm{DZ}) \quad(\mathrm{DX} \times \mathrm{DY} \times \mathrm{DZ}) \quad(\mathrm{DX} \times \mathrm{DY} \times \mathrm{DZ})$

Fig.5 Influence of Mine Size (6[h] after sunrise)

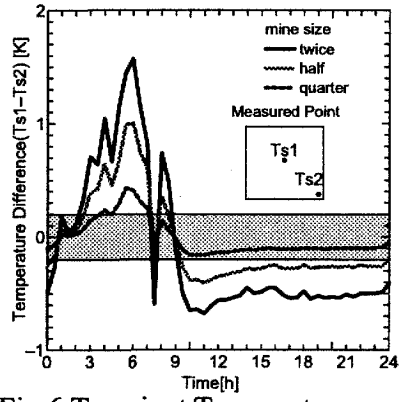

Fig.6 Transient Temperature Difference

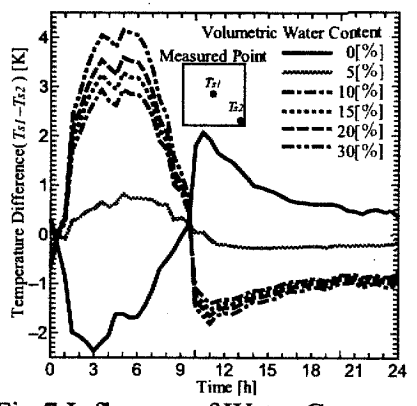

Fig. 7 Influence of Water Content
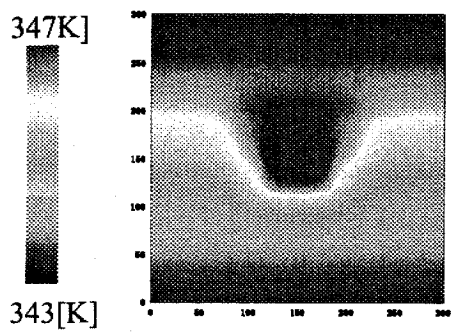

$\varepsilon=1.00$

$\varepsilon=0.96$

$\varepsilon=0.92$

$\varepsilon=0.88$

$\varepsilon=0.84$

$\varepsilon=0.80$

$6[\mathrm{~h}]$ after sunrise

Fig. 8 Thermal Image with Changing Emmisivity 